\title{
Discriminating between Islamic and Conventional banks in terms of cost efficiency with combination of credit risk and interest rate margin in the GCC countries: Does Arab Spring revolution matter?
}

\author{
Mohamed Sadok Gassouma* and Mohamed Ghroubi \\ Higher Institute of Theology, Ez-zitouna University, Tunisia
}

ARTICLE INFO

\section{Article history:}

Received 01 August 2021

Revised 19 September 2021

Accepted 11 October 2021

Published 23 December 2021

Keywords:

Islamic banks

Conventional banks

Cost efficiency

Efficiency stochastic frontier

Credit risk

Regulatory capital

Logistic regression

\section{ABSTRACT}

This study aims to test the contagion effect of the Arab Spring revolution in the GCC countries on discrimination between Islamic and conventional banks in terms of cost efficiency, and to test how prudential factors can influence this comparison. We used the stochastic frontier of Battese and Coelli (1995) to measure the cost efficiency of both Islamic and conventional banks in the GCC countries during 2006_ 2015 (before the Arab revolution 2006-2010 and after the Arab revolution 2011-2015). Second, we used a logit model to discriminate between Islamic and conventional banks in terms of cost efficiency combined with credit risk, regulatory capital and interest margin. Third, we finally test the convergence and divergence between Islamic and Conventional banks by measuring the probability of having Islamic/conventional activities for both banks. We have shown that there is no absolute difference in terms of cost efficiency between Islamic and conventional banks. This difference can be observed through the credit risk taking but not through the interest rate margin. In addition, Islamic banks have taken advantage from the event of the Arab Spring revolution, compared to conventional ones, by being more efficient through risk mitigating due to their participatory financial product. Unlike previous research, we have used a cost efficiency measurement following Battese and Coelli's (1995) model and we have incorporated it in a logit model, in the context of crisis. Cost efficiency is combined with a set of prudential factors to determine their effect on the convergence/divergence between Islamic and conventional bank.

\section{Introduction}

The Arab Spring revolution broke out in Tunisia at the beginning of 2011. This event had an adverse effect on the economy of all countries touched by this event (Tunisia, Libya, Egypt, Yemen, and Syria). According to the banking annual reports in these countries, the Islamic and conventional banking sector was not overly affected by this event.

* Corresponding author.

E-Mail address: gasadok@yahoo.fr

ORCID: 0000-0002-0932-9326 
This revolution did not appear in the Gulf Cooperation Council countries, but it could be transferred through the contagion effect.

The emergence of Islamic banks in the new financial world has raised several questions about their advantage compared to conventional ones. Islamic bank money savings are considered as investment accounts whose owners (depositors) enter into association with investors (creditors) in order to place these accounts in tangible assets. In contrast, conventional bank money savings are supposed to be money supply, which is allocated to the funding of economy, without the association condition in tangible assets. Islamic banks remunerate depositors and creditors based on the profit/loss sharing system with regard to the funding object, called profit rate. The remuneration rate of conventional banks is the same for all depositors and creditors regardless of the nature of projects financed by the investment accounts.

Furthermore, compliance with sharia requirements compels Islamic banks to invest their funds in financial transactions that involve a tangible asset. So, the sale and purchase of debts at a discount, of mortgage loans, and of derivatives are prohibited. Application of Islamic rules precludes also contracts based on speculation and uncertainty “excessive Gharar". (Bhala, 2013)

Moreover, Islamic banks invest their funds only in tangible assets. On the other hand, conventional banks invest their funds in tangible and in monetary goods as speculation and arbitrage operations. However, the Islamic banks' funding cost is the capital cost of tangible goods - called the profit rate. In contrast, conventional banks' funding cost corresponds to tangible and monetary goods, and is called the interest rate.

In terms of risk taking, Islamic banks share their risk with depositor and creditor, who are considered as an investment partner for a limited period (repayment period). The risk of conventional banks is largely borne by the bank itself and partly between depositors and creditors.

All these factors can contribute to the fact that Islamic banks are more efficient in terms of cost compared to conventional ones and vice versa. This hypothesis has been subject to several studies like Abdul-Majid et al. (2008); Johnes et al (2009); Alam (2012); Setiawan et al (2013); Saeed and Izzeldin (2014); and Srairi (2019), that have focused on the comparison between conventional and Islamic banks in terms of efficiency and credit risk. But these authors did not compare these banks in terms of fundamental factors, that is, the interest rate/profit rate establishment in both banks. In addition, they did not specify what factors can influence the efficiency of both banks. On the other hand, they did not suppose that Islamic banks can converge toward conventional banks in terms of sharing risk and interest rate establishment and vice versa.

Our investigation in this paper consists in incorporating the event of Arab Spring revolution in the discrimination between Islamic and conventional banks in GCC countries. The objective is to know if the external event has been transferred to banks of the GCC countries banks in terms of efficiency with combination of the credit risk and the interest margin.

Hence, we can cite our problematic: How can credit risk and interest/profit margin discriminate, in terms of cost efficiency, between Islamic and conventional banks in GCC countries?

In order to carry out our sinvestigation, we will use a set of data for a sample of 90 commercial banks from the Gulf Cooperation Council (GCC) countries, divided into 46 conventional banks and 44 Islamic banks for a sub- 
period: before the Arab revolution (2006-2010) and after the Arab revolution (2011-2015). Firstly, we will opt for Battese and Coelli (1995) model to measure Islamic and conventional banks' cost efficiency and we will establish two annual efficiency scores for each sub-period. Then, we will adopt a logit model, which incorporates cost efficiency as a main factor of discrimination between Islamic and conventional banks combined with a set of prudential factors provided from the literature review: credit risk and regulatory capital. Besides these factors, we will add the interest margin in order to detect the fundamental difference between Islamic and conventional banks as discussed above. Likewise, the logit model is estimated over the two sub-periods (before and after the Arab revolution), in order to know the effect change of efficiency between Islamic and conventional banks.

To this end, we proceed as follows: Section 1 is devoted to the main literature review of banking efficiency in terms of capital-credit risk and interest margin. Section 2 is dedicated to the methodology that will be followed to derivate and estimate our empirical model including efficiency and their combined factor. Section 3 describes the main empirical results. The last section addresses the conclusion.

\section{Brief Literature Review}

The interest given to the study of the relationship between efficiency and risk has considerably increased especially in the aftermath of the so-called subprime crisis. Most of the studies focused on the relationship between efficiency and credit risk measured by the proportion of non-performing loans or by the loan loss provisions. Sun and Chiang (2011) have widely criticized the general trend of these studies, which overlooked the importance of the other types of risks, such as liquidity risk and market risk.

In addition, other researchers have used a comparative approach in order to study the major determinants of efficiency, and analyze the incidence of the different risk indicators ((Alam, 2012); (Setiawan et al. 2013); (Saeed and Izzeldin, 2014); ( Louhichi and Boujelbene, 2015); (Dulal Miah and Uddin 2017)).

In fact, despite their functional specificities, Islamic banks remain vulnerable to common banking risks, and specifically to the risks related to their intermediation role that can affect their efficiency. According to Ariffin et al., (2009), Islamic and conventional banks face similar risks, though their scope may differ depending on the type of bank. Hussain et Al-Ajmi (2012) have noted that the key risks to which Islamic and conventional banks are exposed are credit risk, liquidity risk, and operational risk.

On the other hand, it has been demonstrated that Islamic banks are the most efficient banks. Srairi (2019), has used a sample of 29 Islamic banks operating in five Gulf Cooperation Council countries over the period 2013-2016. He has shown that the superiority of Islamic banks' performance is due to transparency related to corporate governance, Sharia governance and management risk dimensions. Both types of banks have a positive impact on the stability of all banks.

Many researchers have made a comparison between Islamic and conventional banks by developing and comparing two-efficiency models: one for Islamic banks and another for conventional banks during the subprime crisis : Dulal Miah and Uddin (2017), showed that conventional banks are more efficient in managing cost than their Islamic counterparts. 
However, Islamic banks are more solid in terms of short-term solvency but no such difference exists as far as the long-term stability is concerned. In contrast, Alqahtani and al (2017) have investigated the efficiency of Islamic and conventional banks in the GCC region using DEA and SFA before, during and after the global financial crisis (GFC). Results suggest that during the GFC, Islamic banks were more cost-efficient in comparison to conventional banks. Conversely, during the period subsequent to the GFC, Islamic banks suffered more than conventional banks in terms of profit efficiency and they lost their cost efficiency.

Nevertheless, Johnes et al. (2013) suggest that despite the resilience of Islamic banks during the financial crisis, their performance is expected to be inferior to that of conventional banks. The poor performance of Islamic banks is due to three main reasons: (1) the diversity of Islamic jurisprudence schools, which raises the issue of Islamic banks' product standardization; (2) the size factor, which may be equally decisive; and (3) the fact that Islamic banks are often domestic banks. While some studies have demonstrated a non-significant difference between both types of banks ((Hassan et al. 2009); (Shahid et al., 2010)), others have supported the hypothesis of a low efficiency for Islamic banks compared to conventional ones ((Abdul-Majid et al. 2010); (Johnes et al., 2009) ;( Abdul-Majid et al., 2008, 2011a, b); (Beck et al., 2013)).

So, we can deduce from the above, the first hypothesis : H1: Islamic banks are more efficient and more stable during a crisis than conventional ones.

Kwan and Eisenbeis (1997) have validated a negative relationship between cost efficiency and risk taking through a simultaneous equation model. By integrating non-performing loans into the production function, Hughes et al., (1994) hold an opposing view by supporting the hypothesis according to which there exists a negative relationship between inefficiency and risk taking. Based on a risk aversion hypothesis, these authors suggest that managers incur additional expenses when providing loans and monitoring repayment performance. By using Seemingly Unrelated Regressions (SUR), Altunbas et al., (2007) point out that the most inefficient European banks hold higher capital levels, and have lower credit risks, while the most efficient banks tend to take more risks. Similarly, Deelchand and Padgett (2009) provide evidence of the existence of a negative relationship between risks, measured by a loan loss provisions, and capital. In addition, their findings make it clear that inefficient banks operate with more capital while maintaining a high level of credit risk.

Alam (2012) has studied this relationship based on a sample of Islamic and conventional banks, and has demonstrated the existence of a positive correlation between inefficiency and risk in conventional banks, and a negative one in Islamic banks. Based on the Ratio method, Beck et al., (2013) show that Islamic banks are less efficient, have more capital, and, during the subprime crisis, succeeded in having a better quality of assets.

Using the Stochastic Frontier analysis and the vector autoregressive methodology, Saeed and Izzeldin (2014) discussed the possibility that a causal relationship exists between efficiency and default risk measured by distanceto-default. Analysis of the results shows that for both types of banks, an increase in cost-efficiency causes an increase in default risk (decrease in distance-to-default). Thus, according to this study, default risk and efficiency measurements can serve as an early warning indicator to avoid any possible banking crisis.

Based on Zellner's SUR model, Louati et al., (2016) have assessed the relationship between risk, capital and efficiency through a comparative study between Islamic and conventional banks in countries of the MENA region 
and in Asia. Among the explanatory variables of cost-efficiency, the study has taken into consideration the effects of credit risk, insolvency risk, and liquidity level.

The results obtained show that variation in the cost-efficiency of Islamic banks and that of conventional banks, following variation in insolvency risk and liquidity level, are not the same. However, the cost-efficiency of both types of banks varies in the same way, following variation in credit risk. Using the Stochastic Frontier Analysis (SFA) and Ordinary Least Square (OLS), DulalMiah and Uddin (2017) confirm that conventional banks are more efficient than Islamic banks, and that the latter are more stable in the short term, while no difference is found in the long term.

The Results also show that the best-capitalized banks have the highest inefficiency scores. According to this hypothesis, exogenous events such as regional economic downturns affect the quality of assets by raising the credit risk, and make it more cumbersome. Bank managers should expend management effort and incur additional expenditure, such as loan monitoring and forfeiture of securities to remedy this unfavorable situation.

In this context, we cite the study conducted by Ben Khdiri et al (2015), who have used a set of classification, in terms of credit risk, liquidity risk and performance in the context of the subprime crisis, in order to compare between Islamic and conventional banks, in the GCC countries.

These authors have shown that Islamic banks are more efficient, more competitive, liquid and less risky, but cannot be differentiated by the last factor. Hence, the comparative advantage of Islamic banks is due to the fact that they do not invest too much in off-balance sheets and in speculative activities.

Therefore, we will test the following hypothesis H2: Risk taking leads Islamic banks to be more efficient than conventional ones.

Theoretically, the main difference between Islamic and conventional banks, consists in the fact that all funds granted by Islamic banks must invest in tangible assets. Therefore, the Islamic interest rate may converge towards the capital cost of the counterparty of these funds that are the tangible assets. The interest rate, in Islamic banks, is supposed to be a profit rate on the tangible assets funded considered as an investment. In contrast, conventional banks, don't attribute their funds necessary to tangible assets. They can finance all types of monetary transactions (commerce and speculation). Our objective, in this model is to know if there is a fundamental difference in terms of the interest rate/profit rate between both banks.

Secho et al (2020), have studied the effect of the interest rate of conventional banks on the Islamic financial instruments, in 13 countries from 2003 to 2017. They showed that the conventional interest rate is negatively correlated with the sale and the lease-financing instrument and is more amplified in more developed Islamic banking jurisdiction. In addition, the risk-sharing financing instruments are out of the interest rate except in the less developed Islamic banking jurisdictions, where the impact is positive. Thereby, theses authors concluded that the sale/leasebased instruments of Islamic banks are similar to their conventional counterparts in terms of risk.

Many studies are interested in the effect of interest rate on the financing instrument of Islamic banks : Ahmad and Abdul Majid (2017) Zulkhibri (2018) Aysan et al. (2018) Hamza and Saadaoui (2018), showed a negative effect of interest rate on Islamic financing instrument. In contrast, Kader and Leong (2009) and Ergec and Arslan (2013), found a positive relationship, while Ibrahim (2016), found that the relationship between interest rate and the Islamic financing instrument is insignificant. 
According to the result of these authors, we can affirm that the conventional interest rate has a strong relationship (negative or positive) with the Islamic financial product based on sale-lease as Mourebaha and Ijara. In contrast, the interest rate has no relationship with the financial product based on risk sharing as Mouchereka and Moudharaba. Therefore, we conclude that Islamic banks use the same remuneration rate (interest rate is the profit rate) in the case of the sale and the lease instrument, while the interest rate is different from the profit rate when the financing instrument is based on risk-sharing.

Therefore, we will test the following hypothesis: H3 : conventional banks are different compared to Islamic banks in terms of conventional interest rate and Islamic profit rate, in the GCC country banks.

\section{Methodology}

Our empirical approach in this paper, consists in comparing between both Islamic and conventional banks, before and after the Arab revolution in the GCC countries. The choice of this political event is to determine its contagion effect in Tunisia, Egypt, Syria, and Yemen, in the Islamic and conventional banks of the GCC region.

We begin by measuring the cost efficiency of both Banks Islamic and conventional, before and after the revolution, according to the Translog model of efficiency proposed by Batis and Coellis (1995). Then we test the statistical signification of efficiency means inequality between Islamic and conventional banks through the means comparison test. After that, we include the efficiency score combined with credit risk and interest margin as a control variable in a logit model. Consequently, through this model, it will be possible to know the marginal contribution of efficiency interacting with credit risk and interest margin in discrimination between Islamic banks and conventional ones.

\section{Data}

The sample consists of 90 commercial banks from the Gulf Cooperation Council (GCC) countries, divided into 46 conventional banks and 44 Islamic banks. The study period extends over two periods: Before the Arab revolution (2006-2010) and after the Arab revolution (2011-2015). The data have been taken from the Bankscope database.

\section{Measure of Islamic and conventional bank cost efficiency : before and after Arab revolution}

In order to estimate bank efficiency, we use the methodology of Battese \& Coelli (1995). Generally, the cost function reads as follows:

$$
\operatorname{Ln} C_{i t}=C\left(Y_{i t} ; P_{i t} ; \alpha\right)+\varepsilon_{i t}
$$

Where $\mathbf{C}_{\mathbf{i t}}$ represents the noted total cost of bank i during period t; $\mathbf{Y}_{\text {it }}$ represents bank output vector; $\mathbf{P}_{\text {it }}$ is the input price vector and $\alpha$ represents the unknown parameter vector assigned respectively to input and output variables in the cost function. In fact, we introduce two output variables: loans $\left(\mathrm{Y}_{1}\right)$, other earning assets $\left(\mathrm{Y}_{2}\right)$ and two input variables: cost of loanable funds (P1) and labor cost (P2). In addition, equity (Equity) is always used as a quasi-fixed input in the banking cost functions. 
Table 1. Descriptive statistic of Input and output of the efficiency function in the overall period

\begin{tabular}{|c|c|c|c|c|}
\hline \multirow{3}{*}{$\begin{array}{c}\text { Variable } \\
\text { Y1 }\end{array}$} & \multicolumn{2}{|c|}{ Before Revolution } & \multicolumn{2}{|c|}{ After Revolution } \\
\hline & Conventional & Islamic & Conventional & Islamic \\
\hline & 12150.19 & 4970.548 & 17127.48 & 8008.213 \\
\hline & $(11975.37)$ & $(7767.45)$ & $(17232.07)$ & $(11700.36)$ \\
\hline & $\mathrm{N}=216$ & $\mathrm{~N}=162$ & $\mathrm{~N}=226$ & $\mathrm{~N}=184$ \\
\hline \multirow[t]{3}{*}{$\mathbf{Y} 2$} & 5407.61 & 2208.773 & 6921.982 & 37920.34 \\
\hline & $(6037.443)$ & $(2886.144)$ & $(7811.052)$ & $(120415)$ \\
\hline & $\mathrm{N}=216$ & $\mathrm{~N}=163$ & $\mathrm{~N}=226$ & $\mathrm{~N}=185$ \\
\hline \multirow[t]{3}{*}{ P1 } & 309.4231 & 172.2706 & 152.6725 & 1737.176 \\
\hline & $(315.2039)$ & $(210.251)$ & $(1492947)$ & $(9094.155)$ \\
\hline & $\mathrm{N}=195$ & $\mathrm{~N}=65$ & $\mathrm{~N}=214$ & $\mathrm{~N}=110$ \\
\hline \multirow[t]{3}{*}{$\mathbf{P 2}$} & 0.0219 & 0.0234 & 0.0256 & 0.0141 \\
\hline & $(0.0909879)$ & $(0.0491553)$ & $(0.1141)$ & $(0.01939)$ \\
\hline & $\mathrm{N}=215$ & $\mathrm{~N}=157$ & $\mathrm{~N}=226$ & $\mathrm{~N}=182$ \\
\hline \multirow[t]{3}{*}{ Equity } & 198391.4 & 159992.8 & 315699.6 & 2524821 \\
\hline & (201611.6) & (208332.2) & $(324362.1)$ & (7852604) \\
\hline & $\mathrm{N}=215$ & $\mathrm{~N}=128$ & $\mathrm{~N}=229$ & $\mathrm{~N}=171$ \\
\hline
\end{tabular}

*Means of variables; **Std.Dev of variables; ***Number of panel data Y1 = Loans; Y2 = Other earning assets;

$\mathrm{P} 1=\frac{\text { interest expenditure }}{\text { total deposit }} ; \mathrm{P} 2=\frac{\text { Personnel expenses }}{\text { total assets }}$

$\operatorname{Ln}\left[\frac{\mathrm{CT}_{1 \mathrm{t}}}{\mathrm{P}_{2}}\right]=\alpha_{0}+\alpha_{1} \ln \left(\mathrm{Y}_{1}\right)+\alpha_{2} \ln \left(\mathrm{Y}_{2}\right)+\alpha_{3} \ln \left(\frac{\mathrm{P}_{1}}{\mathrm{P}_{2}}\right)+\alpha_{4} \frac{1}{2} \ln \left(\mathrm{Y}_{1}\right)^{2}+\alpha_{5} \ln \left(\mathrm{Y}_{1}\right) \ln \left(\mathrm{Y}_{2}\right)+$

$\alpha_{6} \frac{1}{2} \ln \left(Y_{2}\right)^{2}+\alpha_{7} \frac{1}{2} \ln \left(\frac{P_{1}}{P_{2}}\right)+\alpha_{8} \ln \left(Y_{1}\right) \ln \left(\frac{P_{1}}{P_{2}}\right)^{2}+$

$\alpha_{9} \ln \left(Y_{2}\right) \ln \left(\frac{P_{1}}{P_{2}}\right) \quad+\alpha_{10} \ln ($ Equíty $)+\alpha_{11} \frac{1}{2} \ln (\text { Equity })^{2}+\alpha_{12} \ln ($ Equity $) \ln \left(Y_{1}\right)+$

$\alpha_{13} \ln ($ Equity $) \ln \left(Y_{2}\right)+\alpha_{14} \ln ($ Equity $) \ln \left(\frac{P_{1}}{P_{2}}\right)+u_{\text {it }}+v_{\text {it }}$

In accordance with Battese \& Coelli (1995), the coefficients of equation (1) are estimated using the maximumlikelihood method.

The error term of the cost function is represented by $\varepsilon_{\text {it }}$ and reflected as follows:

$$
\varepsilon_{i t}=\mathbf{U}_{i t}+\mathbf{V}_{\text {it }}
$$

Where $\mathrm{V}_{\mathrm{it}}$ 's are random errors that reflect statistical noise and $\mathrm{U}_{\mathrm{it}}$ 's are random non-negative terms of inefficiency. The cost efficiency is expressed by $\exp \left(\mathbf{U}_{\mathbf{i}}\right)$.

Table 2. Results of specification tests of cost efficiency function estimated before revolution

\begin{tabular}{lllll}
\hline & Conventional Efficiency Cost & Islamic Efficiency Cost & $\begin{array}{l}\text { Conventional } \\
\text { Efficiency Cost }\end{array}$ & $\begin{array}{l}\text { Islamic } \\
\text { Efficiency } \\
\text { Cost }\end{array}$ \\
\hline Wald Khi-square & $2.13 \mathrm{e} 08 * * *$ & & $7566.85 * * *$ & $6.54505 * * *$ \\
Log likelihood & 110.5075 & $1.41 \mathrm{e} 10 * * *$ & 110.5075 & 76.3908 \\
sigma_u & $2.7719 * * *$ & 55.3384 & $0.6401 * * *$ & $0.3646 * * *$ \\
& $(27.69)$ & $5.32 * *$ & $(6.10)$ & $(5.75)$ \\
sigma_v & $3.45 \mathrm{e}-06 * *$ & $(2.87)$ & $0.0508 * *$ & $0.0812 * * *$ \\
& $(2.36)$ & $3.35 \mathrm{e}-07 * *$ & $(2.11)$ & $(4.05)$ \\
Inefficiency statistic & $802660.9 * * *$ & $(2.07)$ & $12.5834 * * *$ & $4.4867 * * *$ \\
Critical value & $7.302 * * *$ & $1.59 \mathrm{e} 07 * * *$ & $0.912 * * *$ & $1.796 * * *$ \\
Test Result & Reject H0 & 2.556 & Reject H0 & Reject H0 \\
\hline
\end{tabular}


aTest of existence of technical inefficiency effect

H0 : Absence of technical inefficiency effect : Lambda $=0 \quad\left(\lambda=\frac{\sigma^{2}(U)}{\sigma^{2}(U)+\sigma^{2}(V)}\right)$

$\mathrm{H} 1$ : existence of technical inefficiency effect : Lambda $>0$

Rejection of (H0) if inefficiency statistic > critical value

Table 3.1. Cost efficiency measurements for selected Islamic and conventional banks : (the pre-revolutionary period:20062010)

\begin{tabular}{lll}
\hline & Conventional Banks & Islamic Banks \\
\hline Variable & Mean/std deviation & Mean/std deviation \\
$\mathbf{2 0 0 6}$ & 0.8716 & 0.7814 \\
& $(0.1178)$ & $(0.1871)$ \\
$\mathbf{2 0 0 7}$ & 0.8144 & 0.7489 \\
& $(0.1902)$ & $(0.2108)$ \\
$\mathbf{2 0 0 8}$ & 0.8034 & 0.7764 \\
& $(0.1615)$ & $(0.193)$ \\
$\mathbf{2 0 0 9}$ & 0.8231 & 0.8146 \\
$\mathbf{2 0 1 0}$ & $(0.1839)$ & $(0.2212)$ \\
& 0.8534 & 0.8156 \\
\hline
\end{tabular}

Table 3.2. cost efficiency measurements for selected Islamic and conventional banks : (the post-revolutionary period: 20112015)

\begin{tabular}{lll}
\hline & Conventional Banks & Islamic Banks \\
\hline Variable & Mean/std deviation & Mean/std deviation \\
2011 & 0.8645 & 0.8891 \\
& $(0.1661)$ & $(0.108)$ \\
2012 & 0.8652 & 0.8904 \\
& $(0.1483)$ & $(0.1002)$ \\
2013 & 0.8308 & 0.8935 \\
& $(0.1985)$ & $(0.0942)$ \\
2014 & 0.8285 & 0.9008 \\
& $(0.2016)$ & $(0.0848)$ \\
2015 & $(0.1839)$ & $(0.2212)$ \\
& 0.8348 & 0.8894 \\
& $(0.1684)$ & $(0.1091)$ \\
\hline
\end{tabular}

Comparison between Islamic and conventional banks in terms of cost efficiency

According to graph.1.1 and graph.1.2 below, we conclude that before the revolution, Islamic banks were more efficient than conventional ones from 2006 until the Arab revolution event in 2010. After this event, Islamic banks became more efficient compared to conventional ones.

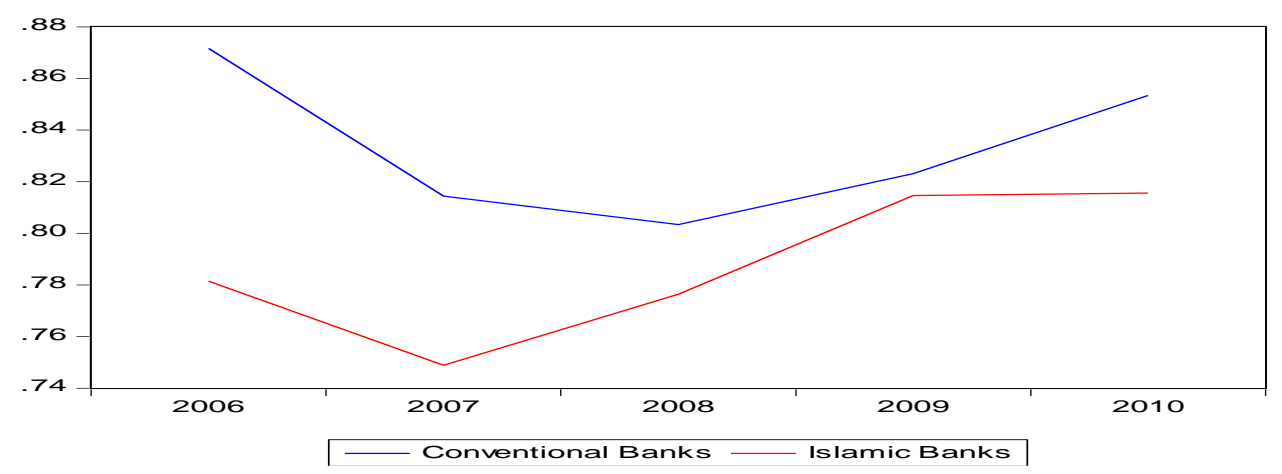

Figure 1.1. Evolution of cost efficiency for selected conventional and Islamic banks: (the pre-revolutionary period:2006-2010) 


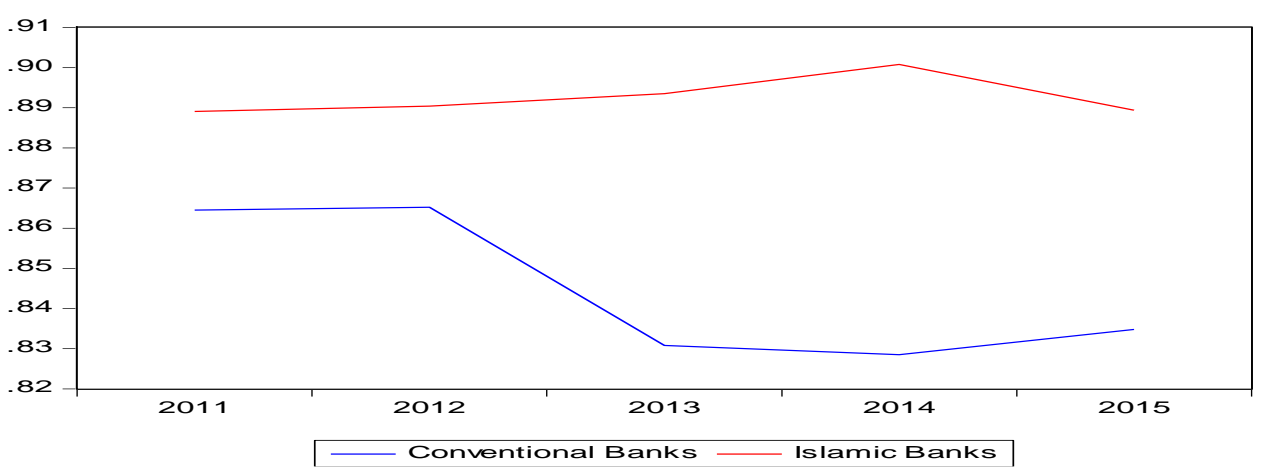

Figure.1.2. Evolution of cost efficiency for selected conventional and Islamic banks: (the post-revolutionary period: 20112015)

Accordingly, to explain the last finding, and in order to detect which is the most efficient type of banks, we opt to test the position of Islamic banks' efficiencies compared to conventional ones; using the test of the mean difference ${ }^{1}$ between Islamic and conventional banks.

Table 4. Islamic and conventional bank efficiency Test of means comparison: before and after the revolution

\begin{tabular}{ccc}
\hline & Before revolution & After Revolution \\
\hline Mean Conventional Bank Efficiency & 0.8316 & 0,8445 \\
Mean Islamic Bank Efficiency & 0.7895 & 0,8929 \\
Difference : Mean Conv - Mean IsL & 0.0421 & $-0,0484$ \\
H1a $:$ Diff $<\mathbf{0}$ & 0,1436 & 0,4116 \\
H1b: Diff!=0 & 0,2873 & 0,2231 \\
H1c $:$ Diff $>\mathbf{0}$ & 0,8564 & 0,9884 \\
\hline
\end{tabular}

*** Means or difference of means that is statistically significant at the $1 \%$ level. ** Means or difference of means that is statistically significant at the 5\% level. * Means or difference of means that is statistically significant at the $10 \%$ level.

Tab.4 reports the result of the test of means differences. We observe that all value of efficiency means difference test, between Islamic and conventional banks, are not significant. We can confirm that all statistical tests of efficiency means inequality are rejected. Therefore, there are no differences in terms of efficiency between the two types of banks. Thus, both banks have the same fundamental factors of cost efficiency.

This last result, rejects all hypothesis and conclusion of efficiency differentiation between both Islamic and conventional banks. Consequently, we invalidate hypothesis 1 that Islamic banks are more efficient and more stable

\footnotetext{
${ }^{1} \mathrm{H} 0$ : There is no-difference between efficiency means of Islamic banks and conventional banks.

H1: difference between efficiency means of Islamic banks and conventional banks is different from zero. From this hypothesis, two sub-hypotheses arise:
}

H1a: The efficiency means of Islamic banks is higher than that of conventional banks.

$\mathrm{H} 1 \mathrm{~b}$ : The efficiency means of Islamic banks is lower than that of conventional banks. 
during crises than conventional banks (Alqahtani and al, 2017; Hsan and Dridi, 2010; Ftiti et al, 2013; Frooq and Zaheer, 2015) and confirm that both banks are similar and we cannot have an absolute discrimination between them.

Discrimination between Islamic and conventional banks in terms of efficiency, through the interest margin, credit risk and regulatory capital

To study the discriminative ability of efficiency and its intersection with a set of prudential factors, we use a probabilistic Logarithmic model. Our idea is inspired by Ben Khediri et al. (2015), who used this model to examine whether financial ratios can be used to distinguish between Islamic and conventional banks.

In our paper, we are taking this model as reference, but by incorporating the score cost efficiency as principal variables that are combined with a set of prudential factors to know the effect of the last factors on efficiency discrimination between both Islamic and conventional banks.

The global model constructed is as follows:

$$
\operatorname{Ln}\left(\frac{P r}{1-P r}\right)=\alpha_{0}+\alpha_{1} E F F+\alpha_{2} R I S K * E F F+\alpha_{3} R E G * E F F+\alpha_{4} M I * E F F
$$

We are granting ( 1 )as a prior probability for Islamic banks $(\boldsymbol{P r})$ and $(0)$ for conventional banks. By applying this model, we get the efficiency power discrimination in terms of credit risk, capital regulatory and intermediation margin, between Islamic and conventional banks.

Our principal variable is cost efficiency (EFF). It was calculated in the last section as the cost efficiency score, which was extracted from Batis et Coellis (1995) model.

In order to test the first hypothesis and based on Berger and DeYoung (1997); Altunbas et al (2000); Fiordelisi et al (2011); Beck et al (2013); Kabir et al (2015) ; Louati et al (2016); Mohanty et al (2016); Mester (1993), we have added a variable that measures credit risk (RISK) : the ratio of non-performing loans on the total loans.

Additionally, to answer the second hypothesis, we have added the rate of regulatory capital provided to cover the amount of credit risk (REG). This variable is measured in each bank, according to the Basel 3 settlement. It reflects the degree of risk control.

Finally, to test the third hypothesis, we have used a proxy variable that tells us about the interest/profit rate in both banks. This variable is the intermediation margin (MI), which measures the margin of interest rate/profit rate in both banks.

These three variables (RISK, REG, MI), are integrated in this model as combined variables with efficiency, in order to determine their effect on discrimination between Islamic and conventional banks, in terms of efficiency.

To extract the effect of these three variables, we will divide the global model into three sub-models. Each model contains the principal variable (EFF) and its combination with theses control variables:

Modèle 1 : $\operatorname{Ln}\left(\frac{P r}{1-P r}\right)=\alpha_{0}+\alpha_{1} E F F+\alpha_{2} E F F * R I S K$

Modèle $2: \operatorname{Ln}\left(\frac{P r}{1-P r}\right)=\beta_{0}+\beta_{1} E F F+\beta_{2} E F F * R E G$

Modèle $3: \operatorname{Ln}\left(\frac{P r}{1-P r}\right)=\gamma_{0}+\gamma_{1} E F F+\gamma_{2} E F F * M I$ 
We estimate the four models using the Maximum Likelihood Estimation : The global model is used to measure the global probability of being an Islamic/conventional status for both Islamic and conventional ones. Moreover, model.1, model.2 and model.3, are used to determine the effect of : credit risk, regulatory capital and interest margin, respectively on the discrimination between both banks in terms of efficiency

Table 5. Descriptive statistic of Logit model variables

\begin{tabular}{|c|c|c|c|c|c|c|}
\hline \multirow[b]{2}{*}{ Variable } & \multicolumn{3}{|c|}{ Before Revolution } & \multicolumn{3}{|c|}{ After Revolution } \\
\hline & Conventional & Islamic & P-value & Conventional & Islamic & P-value \\
\hline \multirow[t]{3}{*}{ EFF } & 0.8316 & 0.7895 & $0.0873 *$ & 0.8445 & 0.8929 & $0.0231 * *$ \\
\hline & $(0.1573)$ & $(0.197)$ & & $(0.1782)$ & $(0.0986)$ & \\
\hline & $\mathrm{N}=232$ & $\mathrm{~N}=211$ & & $\mathrm{~N}=319$ & $\mathrm{~N}=317$ & \\
\hline \multirow[t]{3}{*}{ RISK } & 3.8137 & 5.6057 & $0.0042 * * *$ & 4.1825 & 6.0860 & $0.015 * *$ \\
\hline & $(2.9738)$ & $(7.9093)$ & & $(2.4587)$ & (11.3547) & \\
\hline & $\mathrm{N}=208$ & $\mathrm{~N}=102$ & & $\mathrm{~N}=226$ & $\mathrm{~N}=159$ & \\
\hline \multirow[t]{3}{*}{ REG } & 17.5806 & 29.1431 & $0.000 * * *$ & 19.4139 & 24.7338 & $0.0003 * * *$ \\
\hline & $(4.7796)$ & $(23.8963)$ & & $(5.8037)$ & (20.6989) & \\
\hline & $\mathrm{N}=204$ & $\mathrm{~N}=87$ & & $\mathrm{~N}=224$ & $\mathrm{~N}=142$ & \\
\hline \multirow[t]{3}{*}{ MI } & 3.1217 & 4.0126 & 0.1637 & 3.1459 & 2.5918 & 0.312 \\
\hline & $(0.9907)$ & $(6.7776)$ & & $(1.2893)$ & $(2.3919)$ & \\
\hline & $\mathrm{N}=207$ & $\mathrm{~N}=126$ & & $\mathrm{~N}=226$ & $\mathrm{~N}=175$ & \\
\hline
\end{tabular}

Notes: This table reports the mean of variables for Islamic and conventional banks, and the p-value for the T-test of differences in means between the two groups of banks. The T-test for equality of means is calculated assuming unequal sample variances.

$*$ Significance at $10 \%$ level. $* *$ Significance at $5 \%$ level.***Significance at $1 \%$ level.

\section{Results and Discussions}

Model.1 (See table.6) reports the effect of credit risk on the ability of efficiency to discriminate between Islamic and conventional banks. In fact, our aim was to determine the effect of credit risk on the relationship between efficiency and the probability to be an Islamic bank or conventional one. To do this, we have established the derivative of model.1 compared to efficiency. Hence, we have found that the cutting thresholds of credit risk from which the relationship between efficiency and nature of banks changes in terms of sign.

Before the revolution, when credit risk is below $1.52 \%{ }^{2}$, Islamic banks are more efficient than conventional ones. On the contrary, the credit risk taking (above 1.52\%), leads conventional banks to be more efficient.

After the revolution, a low degree of credit risk (below $0.3 \%$,) leads conventional banks to be more efficient than Islamic ones. In contrast, a high degree of credit risk leads conventional banks to be more efficient than Islamic ones.

\footnotetext{
${ }^{2}$ Model 1 reports the effect of credit risk on the relationship between efficiency and the discrimination between Islamic and conventional banks measured by ( $(\operatorname{Pr} /(1-\mathrm{Pr}))$. To know the effect change, we determine the cutting value of the credit risk, by deriving the output of this model compared to efficiency as follows:
}

$\frac{\delta \text { L before }}{\partial E F F}-0.1373+0.09$ RISK $=0$, RISK $^{*}=1.52$ where RISK $*$ is the cutting thresholds of credit risk (RISK in Database is expressed in integer number) : RISK $=1.52 \%$.

$\frac{\delta \text { L after }}{\partial E F F}=0.1429-0.044$ RISK $=0$, RISK $^{*}=3.24$ where RISK $*$ is the cutting thresholds of credit risk (RISK in Database is expressed in integer number) : RISK $=3.24 \%$. 
This result shows that, the Arab Spring revolution has a decisive impact on risk taking behavior on the efficiency discrimination between both banks. This event, has allowed Islamic banks in the GCC countries to mitigate their risk taking unlike conventional banks. In fact, Islamic banks are positively influenced by the Arab revolution, which took advantage of the revolution context, to be more efficient without taking credit risk.

Likewise, model.2 (See table.6) reflects the effect of regulatory capital (REG) the ability of efficiency to discriminate between both banks. When regulatory capital is above $8.85 \%$ (Before revolution) and $11.98 \%$ (After revolution), conventional banks are more efficient than conventional ones. Beyond, the thresholds, Islamic banks become more efficient. This situation, has accrued in each period (overall, before the revolution and after the revolution)

Therefore, the status of Islamic banks requires having more regulatory capital to cover credit risk, in order to be efficient as required by the Sharia Board based on the result of Safuillah and Shamsuddine (2019). These latter found that Sharia Board with higher academic qualifications and reputation of their members, is the main source of efficiency in Islamic banks, unlike conventional banks that are dispensed of Sharia Board, an increase in capital incurs more costs and consequently reduces their efficiency.

In conclusion, the Arab Spring revolution, has prompted Islamic banks to mitigate their risk and to devote more required capital to be more efficient. In contrast, this event encourages conventional banks to take more risk by reducing their capital requirement and investing in risky projects to be more efficient than Islamic ones.

We can therefore invalidate hypothesis 2 that an increase in credit risk does not lead Islamic banks to be more efficient than conventional ones.

The effect of the intermediation margin in model.3 (See table.6) is not significant. However, we cannot derivate this model and deduct the interest margin thresholds, which confirms that conventional and Islamic banks cannot be differentiated using the intermediation margin.

This result can be due to the incorrect derivation of Islamic interest rate(s)/profit rate compared to that of conventional ones. In the literature, the interest rate of Islamic banks is the discount rate of the real market of goods and services, considered as profit rate. In fact, Islamic banks employed a profit rate issued from the real market of goods and services that can be adjusted by the money capital cost of the monetary market practiced in conventional banks.

Our result is consistent with those of Secho et al (2020), Ahmad and Abdul Majid (2017) Zulkhibri (2018) Aysan et al. (2018) Hamza and Saadaoui (2018), Kader and Leong (2009) Ergec and Arslan (2013), who have shown that there is no difference between conventional interest rate and Islamic profit rate, since the conventional interest rate has a strong significant effect on Islamic financing instrument.

\footnotetext{
${ }^{3}$ Model 2, reports the effect of regulatory capital on the relationship between efficiency and the discrimination between Islamic and conventional banks measured by ( $\mathrm{Pr} /(1-\mathrm{pr}))$. The cutting regulatory capital is determined as follows :

$\frac{\delta L \text { before }}{\partial E F F}=-1.2419+0.1402 R E G=0, \mathrm{REG}=8.85$. (REG in Database is expressed in decimal number) $: \mathrm{REG}=8.85 \%$

$\frac{\delta L \text { after }}{\partial E F F}=-0.6398+0.0534 R E G=0, \mathrm{REG}=11.98$. (REG in Database is expressed in decimal number) $: \mathrm{REG}=11.98 \%$.
} 
We can, therefore, invalidate hypothesis 3 that conventional banks are different compared to Islamic banks in terms of conventional interest rate and Islamic profit rate, in the GCC country banks.

Table 6. Result Estimation of Logit model: before and after the revolution

\begin{tabular}{|c|c|c|c|c|c|c|c|c|}
\hline & \multicolumn{3}{|c|}{ Before Revolution } & \multicolumn{4}{|c|}{ After Revolution } & \\
\hline \multirow{4}{*}{ EFF } & Model 1 & Model 2 & Model 3 & Global & Model 1 & Model 2 & Model 3 & Global \\
\hline & $-0.1373^{*}$ & -1.2419 & -0.3856 & $-1.3257 * * *$ & 0.1429 & -0.6398 & $1.1209 *$ & $0.2559^{*}$ \\
\hline & $(-2.13)$ & $(-1.02)$ & $(2.37)$ & $(-2.99)$ & $(1.33)$ & $(-1.59)$ & (2.06) & $(2.23)$ \\
\hline & $(0.098)$ & $(0.309)$ & $(0.012)$ & $(0.002)$ & $(0.41)$ & $(0.56)$ & $(0.090)$ & $(0.082)$ \\
\hline \multirow[t]{2}{*}{ EFF*RISK } & $0.090 * * *$ & & & $-0.1842 * *$ & $-0.044 * *$ & & & $0.004 *$ \\
\hline & (3.42) & & & $(-2.07)$ & $(-2.5)$ & & & (2.09) \\
\hline \multirow[t]{3}{*}{ EFF*REG } & & $0.1402 * * *$ & & $0.1714 * * *$ & & $0.0534 * * *$ & & $0.0505 * *$ \\
\hline & & $(5.29)$ & & $(4.14)$ & & $(2.93)$ & & (2.4) \\
\hline & & $(0.000)$ & & $(0.000)$ & & $(0.003)$ & & $(0.017)$ \\
\hline \multirow[t]{3}{*}{ EFF*MI } & & & 0.0404 & 0.3602 & & & -0.1732 & -0.1415 \\
\hline & & & $(1.52)$ & $(0.22)$ & & & $(-1.19)$ & $(-1.27)$ \\
\hline & & & $(0.129)$ & $(0.291)$ & & & $(0.233)$ & $(0.202)$ \\
\hline \multirow[t]{3}{*}{ _cons } & $-0.8590 * *$ & $-1.9646^{* *}$ & $-0.6228^{*}$ & $-1.9759 * *$ & $-0.5868 * *$ & $-0.6069^{*}$ & $-0.5494^{*}$ & $-0.564 * *$ \\
\hline & $(-2.91)$ & $(-1.96)$ & $(-2.69)$ & $(-2.00)$ & $(-2.66)$ & $(-2.67)$ & $(-2.63)$ & $(-2.62)$ \\
\hline & (0.001) & $(0.050)$ & $(0.092)$ & $(0.046)$ & $(0.012)$ & $(0.055)$ & $(0.051)$ & $(0.035)$ \\
\hline Observation & 230 & 217 & 253 & 166 & 236 & 224 & 246 & 288 \\
\hline \multirow[t]{2}{*}{ Wald chi-2 } & $11.71 * * *$ & $28.68 * * *$ & $2.56^{*}$ & $20.28 * * *$ & $6.45 * *$ & $8.63 * *$ & $1.97^{*}$ & $6.66^{*}$ \\
\hline & $(0.0029)$ & $(0.000)$ & $(0.0786)$ & $(0.0004)$ & $(0.0397)$ & $(0.013)$ & $(0.0730)$ & $(0.0549)$ \\
\hline
\end{tabular}

The value in parentheses corresponds to Z-value and the $(\mathrm{P}>\mathrm{z})$ of the coefficient. *** means that the variable is statistically significant at the $1 \%$ level. ** means that the variable is statistically significant at the $5 \%$ level. * means that the variable is statistically significant at the $10 \%$ level.

Referring to global model estimation, we can measure the global probability (Pr) of the logit model as an output score. This output is the probability for each bank (Islamic or conventional) to more converge toward an Islamic bank than conventional ones and vice versa

Tab.7 reports the output result of the global model expressing the probability of being an Islamic bank in terms of efficiency. We note that the conventional and Islamic banks have a probability of being an Islamic bank respectively $37.65 \%$ and $42.84 \%$. This distinction between both types of banks is significant at the $1 \%$ threshold, which prove the validity of our result and highlights the importance of combined variables. Moreover, we notice that this probability increased after the revolution in both banks. The result shows that the fundamental factors of real and financial sphere(s) are present in both banks.

We conclude that there is no significant difference between Islamic and conventional banks as shown by the tests of efficiency means inequality. This confusion between both types of banks, is mainly due to the confusion of their interest rates.

Table 7. Estimation of Islamic Bank probability

\begin{tabular}{lllllll}
\hline & Before Revolution & & & After Revolution & \\
\hline \multirow{4}{*}{$\operatorname{Pr}$} & Conventional & Islamic & Diff & Conventional & Islamic & Diff \\
& 0.3424 & 0.3765 & $-0.095^{* * *}$ & 0.4382 & 0.4284 & $-0.051^{* * *}$ \\
& $(0.658)$ & $(0.0965)$ & & $(0.1665=$ & $(0.1728)$ & \\
\hline
\end{tabular}


Relying on table.5, we note that all variables integrated in logit model, accept the hypothesis of inequality of means between Islamic and conventional banks for all variables (EFF, RISK, REG), except the intermediation margin. The last variable is equal between both banks. Thus, discrimination between Islamic and conventional banks can be observed, as discussed above, through risk taking and regulatory capital requirement and not by the interest rate/profit rate.

\section{Conclusion}

Starting from a theoretical approach that is focused on banking efficiency in conventional and Islamic banks, and based on Beck et al (2013), Johnes (2015), Hsan and Dridi (2010), and Hughes et al (1994), we have tried to derive a logit model that incorporates cost efficiency as a main factor combined with three fundamental factors: credit risk, regulatory capital and interest margin.

This model has been applied to GCC Islamic and conventional banks during 2006-2015 and for two sub-period: from 2006 to 2010 (Before the Arab revolution) and from 2011 to 2015 (After the Arab revolution).

With regard to this model, we have found that there is no absolute discrimination in terms of cost efficiency between Islamic and conventional banks for two main reasons: firstly, the output of the logit model indicates that both Islamic and conventional banks can converge toward Islamic/conventional status $40 \%$, for all periods presented. Secondly, when we observe the interest margin (main characteristic difference between Islamic and conventional banks), for both banks, we conclude that there is no difference in terms of their means, which leads us to affirm that the interest rate/profit rate establishment in Islamic and conventional banks has the same characteristics.

On the other hand, Islamic and conventional banks can be discriminated in terms of cost efficiency through the prudential factor: credit risk and regulatory capital requirement. We have shown that the event of the Arab Spring revolution has an effect on both banks. This event, has led Islamic banks to be more prudent (mitigate their risk taking and devote more capital requirement), to be more efficient than conventional ones. The advantage given to Islamic banks can be due to the participative financial product and the supplementary governance exercised by a Shariah board bisedes the CEO Board, compared to conventional banks.

In summary, we affirm that there is a relative and not an absolute discrimination, between Islamic and conventional banks, which is based on the risk of financial product and not on the remuneration premium of interest rate/profit rate. 


\section{References}

Alqahtani, F., Mayes' D,G., \& Brown,K. (2017). Islamic bank efficiency compared to conventional banks during the global crisis in the GCC region. Journal of International Financial Markets, Institutions and Money (51), 58-74.

Abdul-Majid, M., Saal, D., S. \& Battisti, G. (2011a). Efficiency and total factor productivity change of Malaysian commercial banks. Service Industries Journal 31(13), 2117-2143.

Abdul-Majid, M., Saal, D., S. \& Battisti, G. (2008). The efficiency and productivity of Malaysian banks: an output distance function approach. Aston Business School Research Paper R, P0815.

Abdul-Majid, M., Saal, D., S. \& Battisti, G. (2010). Efficiency in Islamic and conventional banking: An international comparison. Journal of Productivity Analysis, 34(1), 25-43.

Abdul-Majid, M., Saal, D., S. \& Battisti, G.(2011b). The impact of Islamic banking on the cost efficiency and productivity change of Malaysian commercial banks. Applied Economics 43 (16): 2033-3054.

Ahmad, Z., \& Abdul Majid, N. (2017). Islamic bank financing, financial crisis and monetary policy: An interaction in the long run equilibrium. International Journal of Islamic Banking, 2 (1), 15-23.

Alam, N. (2012). Efficiency and risk-taking in dual banking system: Evidence from emerging markets. International Review of Business Research Papers, 8(4), 94-111.

Altunbas, Y., Carbo, S., Gardener, E., P., M., \& Molyneux, P. (2007). Examining the relationships between capital, risk and efficiency in European banking”. European Financial Management 13, 49-70.

Altunbas, Y., Liu, M-H., Molyneux, P. \& Seth, R., (2000). Efficiency and risk in Japanese Banking. Journal of Banking and Finance 24, 1605-1628.

Aysan, A. F., Disli, M., \& Ozturk, H. (2018). Bank lending channel in a dual banking system: Why are Islamic banks so responsive? The World Economy, 41(3), 674-698.

Battese, G., E., D., S., P., Rao, \& C., J., O’Donnell (2004). A Metafrontier Production Function for Estimation of Technical Efficiencies and Technology Gaps for Firms Operating Under Different Technologies”. Journal of Productivity Analysis, 21, 91-103.

Battese. G. E \& T. J. Coelli. (1995). A Model for Technical Inefficiency Effects in a Stochastic Frontier Production Function for Panel Data. Empirical Economics 20 ,325-332

Beck, T., Demirgüç-Kunt, A. \& Merrouche, O. (2013). Islamic vs. Conventional Banking Business Model, Efficiency and Stability. Journal of Banking and Finance 37, 433-447.

Berger, A. \& DeYoung, R. (1997). Problem loans and cost efficiency in commercial banking. Journal of Banking and Finance 21, 849-870.

Berger, A., N., \& Mester, L. (1997). Inside the black box: what explains differences in the efficiencies of financial institutions? Journal of Banking and Finance, 21, 895-947.

Chapra, U. (2008). The Global Financial Crisis and the Islamic Financial System. Paper presented at the Forum On The Global Financial Crisis, Islamic Development Bank.

Deelchand, T. \& Padget,C. (2009). The Relationship between Risk, Capital and Efficiency: Evidence from Japanese Cooperative Banks. ICMA Discussion Paper in Finance, DP 2009-12.

Dulal Miah,M., \& Uddin, H. (2017). Efficiency and stability: A comparative study between islamic and conventional banks in GCC countries. Future Business Journal, 3 (2), 172-185.

Farooq, M. \& Zaheer.S. (2015). Are Islamic banks more resilient during financial panics? Pacific Economic Review, 20 (1), 101-124.

Fiordelisi, F., Marques-lbanez, D. \& Molyneux, P. (2011). Efficiency and risk in European banking. Journal of Banking and Finance, 35, 1315-1326.

Ftiti, Z., Nafti, O. \& Srairi, S. (2013). Efficiency of Islamic banks during subprime crisis: Evidence of GCC countries. The Journal of Applied Business Research, 29 (1), 285-304.

Hamza, H., \& Saadaoui, Z. (2018). Monetary transmission through the debt financing channel of Islamic banks: Does PSIA play a role? Research in International Business and Finance, 45, 557-570.

Hasan, M. and Dridi, J.( 2010). The Effects of the Global Crisis on Islamic and Conventional Banks: A Comparative Study. IMF Working Paper WP/10/201.

Hassan, I., \& Merton, K., (2003). Development and efficiency of the banking sector in a transitional economy: Hungarian banking experience. Journal of Banking and Finance, 27, 2249-2271.

Hassan, T., Mohamad, S. and Bader, M. K. I (2009). Efficiency of conventional versus Islamic banks: evidence from the Middle East. International Journal of Islamic and Middle Eastern Finance and Management, 2 (1), 46-65.

Hughes JP \& Mester L.J. (1998). Bank capitalization and cost: evidence of scale economies in risk management and signaling. Rev Econ Stat, 80 (2), 314-325

Hughes, J., L. Mester, \& C. Moon. (2001). Are scale economies in banking elusive or illusive? Evidence obtained by incorporating capital structure and risk-taking into models of bank production. Journal of Banking and Finance, 25 (12), $2169-$ 2208.

Hughes, J., P., Lang, W., Mester, L., J., \& Moon, C., G.(1994). Recovering Technologies That Account for Generalized Managerial Preferences: An Application to Non-Risk-Neutral Banks. Department of Economics, Rutgers University. 
Hughes, J.P \& Mester, L.J. (1993). A quality and risk-adjusted cost function for banks: Evidence on the 'too-big-to-fall' doctrine. Journal of Productivity Analysis, 4, 293-315.

Hughes, J.P., Mester, L.J. \& Moon, G.J. (2001). Are all scale economies in banking elusive or illusive: evidence obtained by incorporating capital structure and risk taking into models of bank production. Center for Financial Institutions Working Papers 00-33, Wharton School Center for Financial Institutions, University of Pennsylvania

Hughes, JP \& Mester .L (2013). Who said large banks don't experience scale economies? Evidence from a risk-return-driven cost function. Journal of Financial Intermediation, 22 (4), 559-585.

Hussain, H., \& Al-Ajmi, J. (2012). Risk management practices of conventional and Islamic banks In Bahrain. Journal of Risk Finance (Emerald Group Publishing Limited), 13 (3), 215239.

Ibrahim, M. H. (2016). Business cycle and bank lending procyclicality in a dual banking system. Economic Modelling, 55, 127 134.

Johnes, J., Izzeldin, M. and Pappas, V. (2013). A comparison of performance of Islamic and conventional banks 2004 to 2009. Journal of Economic Behavior and Organization.

Johnes, J., M. Izzeldin \& V. Pappas (2009). The efficiency of Islamic and conventional banks in the Gulf Cooperation Council (GCC) countries: An analysis using financial ratios and data envelopment analysis. LUMS Working Papers Series 2009/023 Lancaster University Management School.

Kabir, N., Worthington, A., C., \& Gupta, R. (2015). Comparative credit risk in Islamic and conventional banks. Pacific-Basin Finance Journal.doi: 10.1016/j.pacfin.2015.06.001

Kwan, S. \& Eisenbeis, R.A. (1997). Bank risk, capitalization, and operating efficiency. Journal of Financial Services Research, $12(2-3), 117-131$.

Louati, S. \& Boujelbene,Y.(2015). Banks'stability-efficiency within dual banking system: A stochastic frontier analysis. International Journal of Islamic and Middle Eastern Finance and Management, 8 (4), 472-490.

Louati,S.,Louhichi,A. \& Boujelbene,Y.(2016). The risk-capital-efficiency trilogy: A comparative study between Islamic and conventional bank. Managerial Finance, 42 (12), 1226-1252.

Mester, L. J. (1996). A study of bank efficiency taking into account risk-preferences. Journal of Banking and Finance, 20, 10251045.

Miah.M.D. \& Uddin.H. (2017), "Efficiency and stability: A comparative study between islamic and conventional banks in GCC countries", Future Business Journal 3,172-185

Šeho, M., Bacha,O.I., \& Smolo, E (2020). The effects of interest rate on Islamic bank financing instruments. Pacific-Basin Finance Journal.

Masetti, O., Körner, K., Forster, M., Friedman, J., 2013. “Two years of Arab Spring Where are we now? What's next. Deutsche Bank AG, DB Research Management.

Mohanty, S.K., Lin, H.-J., Aljuhani, E.A. \& Bardesi,H.J.(2016). Banking Efficiency in Gulf Cooperation Council (GCC) Countries: A Comparative Study. Review of Financial Economics.

Nguyen, TPT \& Nghiem, SH.(2015). The interrelationships among default risk, capital ratio and efficiency: evidence from Indian banks. Managerial Finance, 41 (5), 507-25.

Pessarossi, P. \& Weill, L (2015). Do capital requirements affect cost efficiency? Evidence from China. Journal of Financial Stability.http://dx.doi.org/10.1016/j.jfs.2014.11.002

Safiullah,M., \& Shamsuddin,A (2019). Risk-adjusted efficiency and corporate governance: Evidence from Islamic and conventional banks. Journal of Corporate Finance, 55, 105-140.

Saeed, M. \& Izzeldin, M. (2014). Examining the relationship between default risk and efficiency in Islamic and conventional banks. Journal of Economic Behavior and Organization.

Shahid, H., R. Ur Rehman, G. S. K. Niazi \& A. Raoof. (2010). Efficiencies comparison of Islamic and conventional banks of Pakistan. International Research Journal of Finance and Economics, 49, 24-42.

Srairi., S. (2019). Transparency and bank risk-taking in GCC Islamic banking. Borsa Istanbul Review, 19 (1), S64-S74.

Sun, L., and Chang, T. P. (2011). A comprehensive analysis of the effects of risk measures on bank efficiency: Evidence from emerging Asian countries. Journal of Banking \& Finance, 35 (7), 1727-1735.

Zulkhibri, M. (2018). The impact of monetary policy on Islamic bank financing: bank-level evidence from Malaysia. Journal of Economics, Finance and Administrative Science, 23(46), 306-322.

(C) 2021 by the authors. Licensee ACRN Publishing, Austria, Editor in Chief Prof. Dr. Othmar M. Lehner. This article is an open access article distributed under the terms and conditions of the Creative Commons Attribution (CC BY SA) license (https://creativecommons.org/licenses/by-sa/4.0/) 